\title{
Capital Flight from
}

Sub-Saharan African Countries:

Updated Estimates, 1970 - 2010

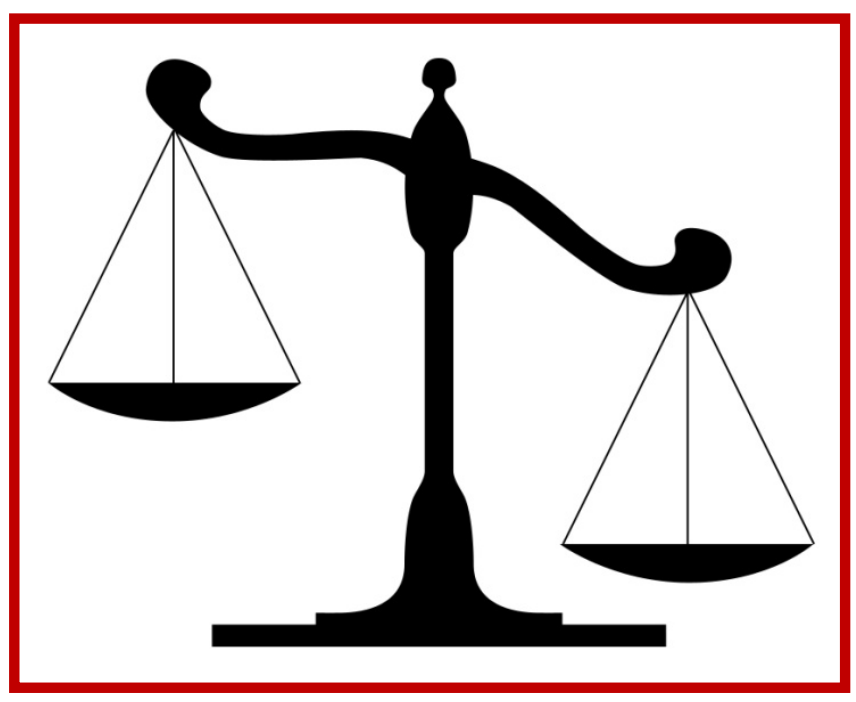

James K. Boyce and

Léonce Ndikumana

Political Economy

Research Institute

University of Massachusetts,

Amherst

October 2012

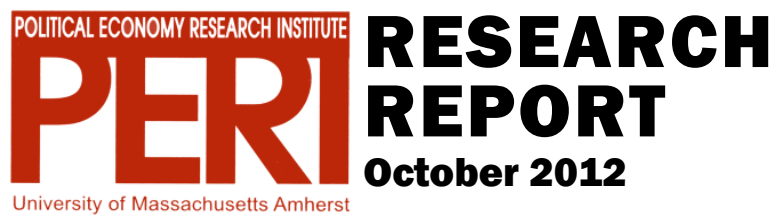


TABLE OF CONTENTS

$\begin{array}{ll}\text { Introduction } & 1\end{array}$

Measurement of capital flight and data sources $\quad 2$

The 'residual' measure of capital flight 2

Trade misinvoicing and unrecorded remittances $\quad 2$

Real capital flight and stock of capital flight

Data sources $\quad 5$

Key methodological differences with existing studies $\quad 6$

Updated estimates of capital flight, 1970-2010 7

$\begin{array}{ll}\text { Capital flight on the rise } & 7\end{array}$

Capital losses through trade misinvoicing and unrecorded remittances $\quad 10$

Capital flight compared to other flows 11

Capital flight is a serious development challenge $\quad 13$

$\begin{array}{ll}\text { Conclusion } & 13\end{array}$

Table 1: Capital flight by country, 1970-2010 9

Table 2: Trade misinvoicing and unrecorded remittances, 1970-2010 10

Table 3: Capital flight, FDI and ODA 11

Figure 1: Capital flight from 33 SSA countries $\quad 7$

Figure 2: Capital flight: oil exporters vs. non-oil exporters 8

Figure 3: Capital flight, FDI, and ODA 12

Figure 4: Net transfers on debt for the 33 countries $\quad 12$

Table A.1: Variables and data sources used in the computations 15

Table A.2: Data availability 16

Table A.3: Capital flight relative to GDP, population \& capital formation 17

Table A.4: Adjustment for trade misinvoicing and unrecorded remittances 18

Table A.5: Capital flight by country, annual time series 1970-2010 19

$\begin{array}{ll}\text { References } & 23\end{array}$

About the authors $\quad 24$

$\begin{array}{ll}\text { About PERI } & 24\end{array}$ 

inspired optimism on the region's prospects for accelerating progress towards its development goals. Before the global financial and economic crisis, sub-Saharan Africa (SSA) grew by an average of over five percent per annum, a major turnaround from the 'lost' decades of the 1980s and 1990s. ${ }^{1}$ Even during the crisis, the sub-continent grew by $3 \%$ in 2009 , trailing only East Asia as the second fastest growing region in the world. These achievements notwithstanding, SSA still faces major development challenges. It is now clear that the majority of the countries in the region will not achieve key millennium development goals. ${ }^{2}$

A key constraint to SSA's growth and development is the shortage of financing. Indeed SSA faces large and growing financing gaps, hindering public investment and social service delivery. At the same time, the sub-region is a source of large-scale capital flight, which escalated during last decade even as the region experienced growth acceleration. The group of $33 \mathrm{SSA}$ countries covered by this report has lost a total of $\$ 814$ billion dollars (constant 2010 US\$) from 1970 to 2010 . This exceeds the amount of official development aid ( $\$ 659$ billion) and foreign direct investment (\$306 billion) received by these countries. Oil-rich countries account for 72 percent of the total capital flight from the sub-region ( $\$ 591$ billion). The escalation of capital flight over the last decade coincided with the steady increase in oil prices prior to the global economic crisis.

Assuming that flight capital has earned (or could have earned) the modest interest rate measured by the short-term United States Treasury Bill rate, the corresponding accumulated stock of capital flight from the 33 countries stands at $\$ 1.06$ trillion in 2010. This far exceeds the external liabilities of this group of countries of $\$ 189$ billion (in 2010), making the region a "net creditor" to the rest of the world. The stereotypical view that SSA is severely indebted and heavily aid-dependent is not fully consistent with the facts.

This report provides updated estimates of capital flight for 33 SSA countries from 1970 to 2010 . It describes the methodology used to estimate capital flight and highlights important methodological differences with other existing studies. The report presents key results on capital flight both in absolute terms and in comparison to other capital flows, especially debt, aid, and foreign direct investment, as well as in relation to the size of the economy (as percentage of GDP and in per capita terms). The report stresses the urgency of efforts to stem capital flight and repatriate stolen assets as a part of the broader goals of scaling up development financing, combating corruption, and improving transparency in the global financial system.

* The authors are grateful to Theresa Owusu-Danso for excellent research assistance.

${ }^{1}$ See AfDB, OECD, UNDP, UNECA. African Economic Outlook (various editions).

${ }^{2}$ See African Development Bank, UNECA, AU, and UNDP (2011)Assessing Progress in Africa toward the Millennium Development Goals, 2011 (MDG Report 2011). 
MEASUREMENT OF CAPITAL FLIGHTAND DATA SOURCES

\section{The 'residual' measure of capital flight}

Capital flight is defined as unrecorded capital flows between a country and the rest of the world. Its measurement starts from the inflows of foreign exchange recorded in the country's Balance of Payments (BoP), in which 'missing money' - the difference between recorded inflows and recorded outflows - is reported as 'net errors and omissions.' Because the BoP data have been found often to under-report external borrowing, data on debt flows are instead taken from the World Bank's Global Development Finance database (www.worldbank.org). The difference between recorded inflows and the recorded uses of foreign exchange provides the baseline 'residual' measure of capital flight (Erbe 1985, World Bank 1985). It is computed as follows:

$K F_{i t}=\triangle D E B T A D J_{i t}+F D I_{i t}-\left(C A_{i t}+\Delta R E S_{i t}\right)$

where $\triangle D E B T A D J$ is the change in the stock of external debt outstanding adjusted for exchange rate fluctuations, ${ }^{3} F D I$ is net foreign direct investment, $C A$ is the current account deficit, and $\triangle R E S$ is net additions to the stock of foreign reserves.

Only a fraction of the 'leakages' revealed by this calculation can be attributed to statistical errors (Lane and Milesi-Ferretti 2007). Many unrecorded flows result from illicit transactions pursued for a variety of motives, including money laundering, tax evasion and tax avoidance. These have been accompanied, and in some cases exacerbated, by the increasing complexity of financial transactions resulting from globalization, the increasing sophistication of operations of multinational corporations with multiple domiciles across the globe, and the expansion of the 'offshore interface between illicit and licit economies' (Christiansen 2009; also see Shaxson 2011, Henry 2012, Baker 2005).

\section{Trade misinvoicing and unrecorded remittances}

Data on external borrowing are not the only numbers that are systematically misreported in official BoP statistics. Trade misinvoicing can substantially distort official measures of exports and imports, and remittance receipts from overseas workers can bypass official recording. Using alternative data sources, we can adjust the simple residual estimate of capital flight to correct for these errors.

\section{Trade mispricing}

Misinvoicing of international trade transactions occurs for several reasons. On the export side, operators may underinvoice exports (by understating their quantity, price, or both) so as to conceal their actual earnings and keep the difference in foreign accounts. This can be an important conduit for capital flight, as our results will illustrate. On the import side, businesses may overinvoice their import bills in

\footnotetext{
${ }^{3}$ See Ndikumana and Boyce (2010) for a detailed algorithm used for exchange rate adjustment of the debt stock.
} 
order to obtain extra foreign currency from banking authorities, again stashing the difference abroad in private accounts or other assets - an analogous mechanism of capital flight. On the other hand, imports may be underinvoiced or not recorded at all so as to circumvent customs duties, phenomena known as 'technical smuggling' and 'pure smuggling,' respectively. Imports must be paid for regardless of whether they are reported in full to the authorities or not. Payments for smuggled imports can be considered another type of illicit financial flow, distinct from capital flight. ${ }^{4}$

The amount of trade misinvoicing is estimated by comparing a country's declared imports and exports statistics to those of its trading partners. For example, exports by Kenya to the United Kingdom, as reported in Kenya's official trade statistics (in the IMF's Direction of Trade Statistics) should equal to the UK's imports from Kenya as declared by the UK in its trade statistics after adding the cost of freight and insurance to the value declared by Kenya. Kenya's imports from the UK are compared to the UK's exports to Kenya in a similar fashion.

Assuming trade statistics reported by advanced economies to be more reliable, we calculate trade misinvoicing of SSA countries relative to this group, and use this as a benchmark to compute overall trade misinvoicing. For an individual SSA country $i$ in year $t$, export discrepancies with industrialized countries $(D X I C)$ are computed as follows:

$$
D X I C_{i t}=P X I C_{i t}-\left(X I C_{i t} * C I F_{t}\right)
$$

where $P X I C$ is the value of imports from the African country as reported by the industrialized trading partners, $X I C$ is the African country's exports to industrialized countries as reported by the African country, and CIF is the c.i.f/f.o.b factor, representing the costs of freight and insurance. ${ }^{5}$

Import discrepancies with the industrialized countries $(D M I C)$ are computed as:

$$
D M I C_{i t}=M I C_{i t}-\left(P M I C_{i t} * C I F_{t}\right)
$$

\footnotetext{
${ }^{4}$ While export misinvoicing and import misinvoicing can be estimated separately from the IMF Direction of Trade Statistics, we cannot use these aggregate data to separate out import overinvoicing and import underinvoicing. Only their net effect can be calculated, which is what matters in estimating total capital flight.

${ }^{5}$ South Africa is the only SSA country that publishes imports at both c.i.f. and f.o.b. in the Direction of Trade Statistics (DOTS), making it possible to compute the c.i.f./f.o.b. factor. For other countries, the factor may be derived using the two values of total imports reported in the DOTS labeled: IFS World Total and DOTS World Total. The ratio of the two should be equal or close to 1.10 , given that the former series is obtained by applying a $10 \%$ factor to the latter according to the IMF's Guide to Direction of Trade Statistics. However, the derived ratios are at times less than 1 and they can fluctuate substantially from one year to another. In our past estimates of capital flight we used the average factor for Africa obtained from IMF's printed DOTS reports, but this information is no longer published. In this report, we use a 1.10 factor for all countries except for South Africa where we use the actual ratio of imports c.i.f to imports f.o.b calculated from DOTS data.
} 
where $M I C$ is the African country's imports from industrialized countries as reported by the African country, and $P M I C$ is the industrialized countries' exports to the African country as reported by the industrialized trading partners.

We scale up the derived value of trade misinvoicing by the inverse of the share of advanced economies in the country's total imports (ICMS) and total exports (ICXS) to obtain a global measure of import and export misinvoicing as follows: ${ }^{6}$

$$
\operatorname{MISINV} V_{i t}=\frac{D X I C_{i t}}{I C X S_{i t}}+\frac{D M I C_{i t}}{I C M S_{i t}}
$$

Total trade misinvoicing is the sum of misinvoicing of exports and misinvoicing of imports. A positive sign on export misinvoicing indicates a net outflow (export underinvoicing) - increasing net capital flight - while a negative sign indicates a net inflow (export overinvoicing) - reducing net capital flight. In most cases, we expect export underinvoicing to dominate export overinvoicing. A positive sign on import misinvoicing again indicates a net outflow (overinvoicing of imports) increasing net capital flight - while a negative sign indicates a net inflow (underinvoicing as a result of import smuggling) - reducing net capital flight. In many cases, smuggling dominates import overinvoicing, resulting in negative import misinvoicing adjustments, and when this is large enough to outweigh net export underinvoicing as well, the overall effect of the misinvoicing adjustment is to reduce estimated capital flight below the simple residual measure. This is because some of the 'missing money' was used to fund the deficit in illicit trade transactions, rather than being counted as an unrecorded capital outflow.

\section{Unrecorded workers' remittances}

Workers' remittances are often under-reported in the official BoP statistics of developing countries. This has the same effect as the underreporting of export earnings. We estimate unrecorded remittances by comparing the country's officially recorded remittances as reported in the $\mathrm{BoP}$ to survey-based estimates compiled by the International Fund for Agricultural Development (IFAD) for the year 2006. ${ }^{7}$ In comparing the two measures, we consider only the IFAD estimates of remittances flows from industrialized countries as they are likely to be more reliable. In principle, the BoP value should be larger because it includes remittances from the entire world, not only from the industrialized countries. When the IFAD estimate exceeds the BoP value, we take this as evidence of underreporting and calculate the discrepancy. We then extrapolate the discrepancy based on IFAD's data for the year 2006 to

\footnotetext{
${ }^{6}$ In past editions of our capital flight series, we used the country's average ICMS and ICXS shares over the sample period. In this report we use the actual annual value. As the time period increases, averaging out these shares implies substantial loss of information. Furthermore using the actual annual ratio will make it easier for any interested user to update the capital flight series as needed in the future.

${ }^{7}$ See Ndikumana and Boyce (2010) for details.
} 
estimate discrepancies for earlier and subsequent years, based on the trend in overall African remittance inflows reported in the $\mathrm{BoP}$ statistics. The formula is as follows:

$R I D_{i t}=\left(A R I_{i, 2006}-B P R I_{i, 2006}\right) * B P R I_{t} / B P R I_{2006}$

where $R I D_{i t}$ is the remittance inflow discrepancy in country $i$ in year $t ; A R I_{i, 2006}$ and $B P R I_{i, 2006}$ are the alternative and $\mathrm{BoP}$ measures, respectively, of remittance inflows in country $i$ in the year 2006; and $B P R I_{t}$ and $B P R I_{2006}$ are the BoP measures of remittance inflows to all African countries as a whole in years $t$ and 2006, respectively.

The total magnitude of capital flight in a given year $t$ for a country $i$ is then obtained by summing up the above components as follows:

$A D J K F_{i t}=\Delta D E B T A D J_{i t}+F D I_{i t}-\left(C A_{i t}+C R E S_{i t}\right)+M I S I N V_{i t}+R I D_{i t}$

\section{Real capital flight and stock of capital flight}

To facilitate analysis of capital flight over time, we express our results in constant 2010 dollars, using the US GDP deflator to convert nominal to real values. We also calculate the accumulated stock of capital flight by imputing interest earnings using the US short-term Treasury bill rate. Of course, not all the capital flight from SSA countries was invested at this rate of return. Some was squandered on extravagant consumption, some may have earned lower returns, and some may have earned higher returns than the rather conservative T-bill benchmark. Regardless, our estimated stock of capital flight provides a measure of opportunity costs to the source country; that is, the benefits foregone by virtue of the loss of capital that could have been invested in infrastructure, health, education, or other productive uses.

\section{Data sources}

\section{Main sources}

The variables used in the in the computation of capital flight are from the IMF's Balance of Payments Statistics (BoP), Direction of Trade Statistics (DOTS), and International Financial Statistics (IFS); the World Bank's World Development Indicators (WDI), and Global Development Finance (GDF). A detailed list of the variables and data sources is provided in Table Al in the appendix (page 17).

\section{Missing DOTS and BOP data}

The electronic DOTS database contains trade data from 1980 onwards only. The data for the 1970s were obtained from printed editions of the DOTS Yearbook. BoP data are reported sparsely in the early years of the 1970s for most countries in the online and CDROM versions of these databases. Thus, printed versions of the BoP were used to fill in the missing data. Up to 1983 , the values in the printed editions of the BoP were reported in Special Drawing Rights (SDRs). The values were 
converted into US dollars (USD) using the USD/SDR exchange rate. For some countries, data were also missing in the $\mathrm{BoP}$ in some years over the 1980-2010 period. We used IMF's online country staff reports to fill these gaps. The concerned years are shown in Table A2 in the appendix.

\section{Debt data}

For some countries the currency composition of long-term debt appears to be incomplete as the sum of the shares of the components does not add up to $100 \%$ in some years. This is the case for Burundi, Cameroon, Cape Verde, Chad, Kenya, Lesotho, Mauritania, and Mozambique. In those years, we used the unadjusted change in debt stock in lieu of $\triangle D E B T A D J$. The concerned countries and the relevant years are also shown in Table A2 in the appendix.

For South Africa, the data on debt and the currency composition of long-term debt are available in WDI/GDF only starting from 1994. We obtained debt stock data for the previous years from the South African Research Bank (online database). ${ }^{8}$ No adjustment for exchange-rate fluctuation for these years was made due to lack of data on the currency composition of long-term debt.

\section{Key methodological difierences with existing studies}

There are some notable differences in the methodologies used in the computation of capital flight in the literature. In addition to the underlying imperfections of the data, these differences partly explain the discrepancies in the magnitudes of the estimates of capital flight across studies. There are three important differences between our approach and the approaches used in some of the existing studies. First, our estimates systematically include trade misinvoicing, which can substantially increase or reduce estimated capital flight. The recent report by the Tax Justice Network (Henry 2012), for example, does not include this important component on grounds of the poor quality of the trade data. In our view, the imperfect data on misinvoicing are more accurate than the alternative assumption that net misinvoicing equals zero.

Second, our methodology includes an estimate of unrecorded remittances. Remittances from overseas workers are a large and growing source private capital inflows in African countries, and they often are substantially underestimated in the official Balance of Payments statistics (see AfDB and World Bank 2011). As noted above, unrecorded remittances have the same effect on capital flight estimates as underreported exports earnings.

Third, we allow for the possibility that there can be 'reverse' flows of capital flight - that is, net unrecorded inflows - in any given country in certain years. That is, capital that left the country may return as economic and political circumstances

${ }^{8}$ Data available at http://www.resbank.co.za/Research/Statistics/Pages/OnlineDownloadFacility.aspx. 
change. We also allow for the possibility that net import misinvoicing (and net trade misinvoicing overall) can result in a downward adjustment of capital flight estimates, as noted above, when import smuggling dominates other sorts of trade misinvoicing. The methodology used by the Washington, DC-based Global Financial Integrity to estimate 'illicit financial flows,' in contrast, sets to zero the values of capital flight and its components (BoP leakages, export and import misinvoicing) when they are negative (see Kar and Cartwright 2010), on the grounds that these 'reversals' should not be deducted from the measure of illicit flows. Our algorithm, which includes both positive and negative inflows in the computation to obtain a 'net' measure of unrecorded capital flows, is the standard practice in the economics literature. Net capital flight provides a measure of the net financial position of the country vis-à-vis the rest of the world resulting from unrecorded crossborder movement of capital. Thus, a positive value of capital flight indicates that the country is transferring to the rest of the world more than it is receiving.

\section{UPDATED ESTIMATES OF CAPITALFLIGHT, 1970-2010}

This section summarizes the results of the estimation of capital flight for the 33 SSA countries covered by this report. Detailed country time series are provided in Table A5 in the appendix.

\section{Capital flight on the rise}

Capital flight from SSA countries is a chronic problem and it has accelerated over the last decade (Figure 1). Between 1970 and 2010 total capital flight from the 33 SSA countries covered in this report amounts to $\$ 814.2$ billion in constant 2010 dollars. These countries lost $\$ 202.4$ billion between 2005 and 2010 alone.

FIGURE 1: CAPITAL FLIGHT FRon 33 SSA COUNThies,

5-YeAR TOTAL NET FLOWS ( BILLION, CONSTANT 2010 DOLLAR)

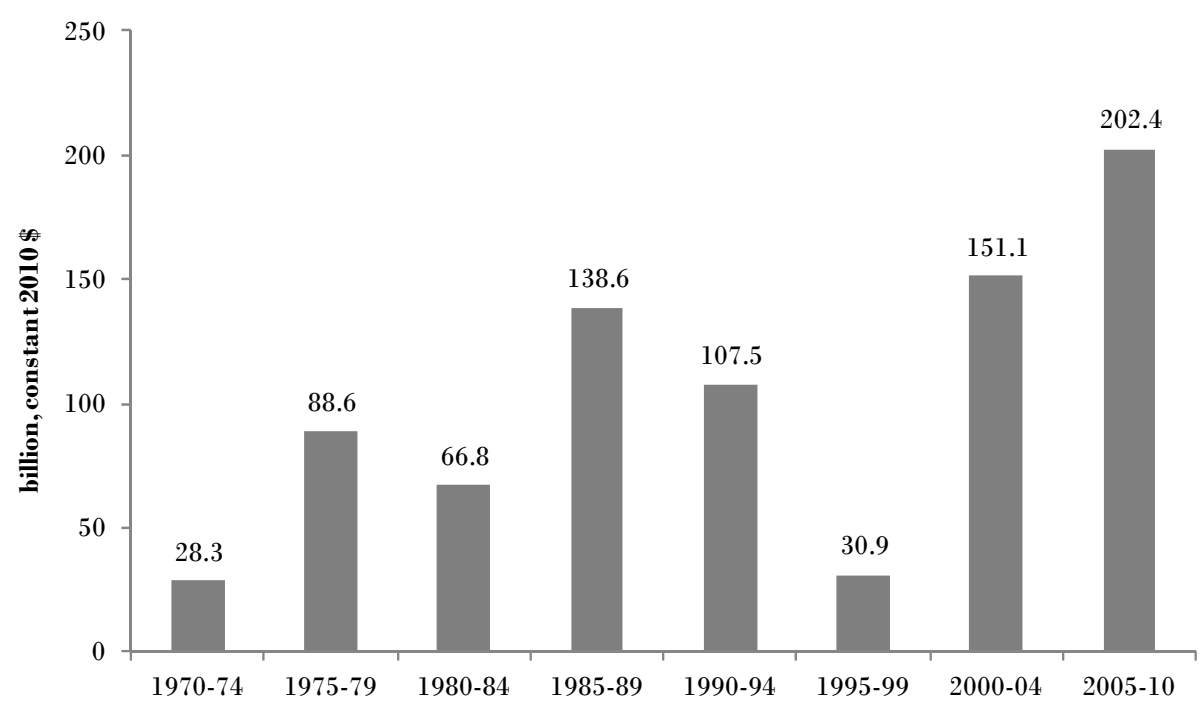

Source: Authors' computations. 
The recent burst of capital flight coincided with the resource boom of the pre-crisis period. Capital outflows rose particularly rapidly among major oil-exporting countries, jumping to a 10-year total of $\$ 325$ in 2000-10 (43 percent of the total), up from $\$ 64$ billion in the 1990 s and $\$ 133$ billion in the 1980s (Figure 2). The group of major oil-exporting countries consists of nine large oil exporters: Angola, Chad, Cameroon, Republic of Congo, Democratic Republic of Congo, Côte d'Ivoire, Gabon, Nigeria and Sudan. Oil exporters are predominantly at the top of the list in terms of volume capital flight, led by Nigeria with total capital flight of $\$ 311$ billion, Angola with $\$ 84$ billion, and Côte d'Ivoire with $\$ 56$ billion (Table 1).

\section{FIGURE 2: CAPITAL FLIGHT: OIL ExPORTERS VS. NON-OIL ExpORTERS ( BILLION, CONSTANT 2010 DOLLARS)}

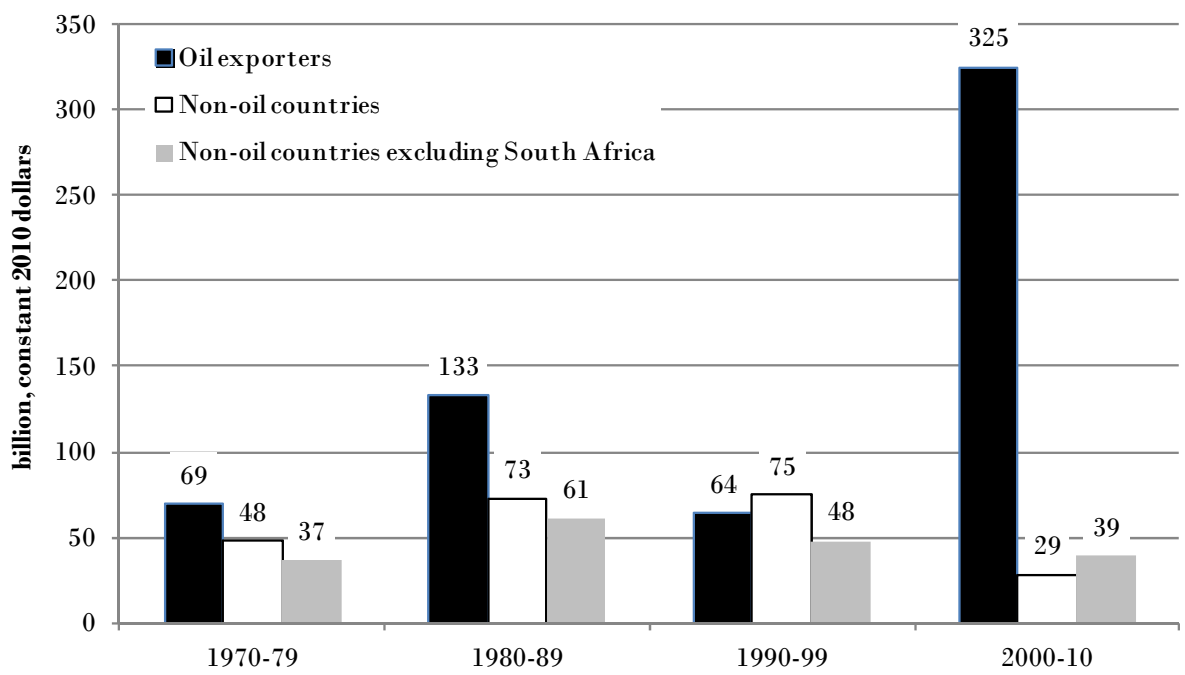

Source: Authors' computations

By 2010, the stock of capital flight including compound interest earnings reached $\$ 1.06$ trillion, which slightly exceeds the combined economic size of these countries as measured by GDP (\$1.05 trillion in 2010). The stock of capital flight also exceeds the $\$ 188.6$ billion of external debt owed by these countries, making them as a group a 'net creditor' to the rest of the world. In other words, these countries could go debt free if they could recuperate just 18 percent of the capital they have lost in unrecorded outflows.

The scale of capital flight is large relative to the size of the economies and the population of these countries (Table A3 in the appendix). In several countries, total real capital flight over the period per capita exceeds current per capita income. In Gabon, capital flight per capita $(\$ 16,911)$ is nearly twice its per capita income $(\$ 8,767)$ in 2010. The same holds for Angola, the Republic of Congo, Côte d'Ivoire and Nigeria. On an annual basis, Gabon lost capital at an average of 41 percent of GDP and $\$ 597$ per capita. The data on capital formation presented in Table A3 suggest that many African countries could achieve a much higher investment rate if they were able to 
TAHLE 1: CAPITAL FLIGHT BY COUNTRY, ITt-2010

(countries are ranked by amount of total capital flight)

\begin{tabular}{|c|c|c|c|c|c|}
\hline Country & $\begin{array}{c}\text { Total capital } \\
\text { flight (billion, } \\
\text { constant } 2010 \$ \text { ) }\end{array}$ & $\begin{array}{c}\text { Ratio to } \\
\text { GDP } 2010 \\
\text { (percent) }\end{array}$ & $\begin{array}{l}\text { Stock capital } \\
\text { flight in } 2010 \\
\text { (billion } \$ \text { ) }\end{array}$ & $\begin{array}{c}\text { Debt stock } \\
\text { in } 2010 \\
\text { (billion } \$ \text { ) }\end{array}$ & $\begin{array}{l}\text { Net assets } \\
\text { in } 2010 \\
\text { (billion } \$ \text { ) }\end{array}$ \\
\hline Nigeria & 311.4 & 158.2 & 381.1 & 7.9 & 373.2 \\
\hline Angola & 84.0 & 101.8 & 95.9 & 18.6 & 77.3 \\
\hline Cote d'Ivoire & 56.0 & 244.4 & 81.3 & 11.4 & 69.9 \\
\hline South Africa & 38.5 & 10.6 & 66.2 & 45.2 & 21.1 \\
\hline Sudan & 38.4 & 57.3 & 42.7 & 21.8 & 20.9 \\
\hline Congo, Democratic Republic & 33.9 & 258.4 & 50.6 & 5.8 & 44.8 \\
\hline Gabon & 25.5 & 192.9 & 31.9 & 2.3 & 29.5 \\
\hline Ethiopia & 24.9 & 83.8 & 29.9 & 7.1 & 22.8 \\
\hline Mozambique & 20.7 & 224.9 & 26.1 & 4.1 & 22.0 \\
\hline Cameroon & 20.0 & 89.0 & 31.3 & 3.0 & 28.3 \\
\hline Congo, Republic & 19.9 & 165.5 & 20.6 & 3.8 & 16.9 \\
\hline Zimbabwe & 18.3 & 244.2 & 25.3 & 5.0 & 20.3 \\
\hline Zambia & 17.3 & 106.7 & 25.6 & 3.7 & 21.9 \\
\hline Tanzania & 14.7 & 64.0 & 26.9 & 8.7 & 18.3 \\
\hline Ghana & 12.4 & 38.4 & 15.5 & 8.4 & 7.1 \\
\hline Madagascar & 11.7 & 134.1 & 17.7 & 2.3 & 15.4 \\
\hline Sierra Leone & 10.0 & 523.6 & 13.8 & 0.8 & 13.0 \\
\hline Rwanda & 9.3 & 165.6 & 18.0 & 0.8 & 17.2 \\
\hline Uganda & 8.4 & 49.0 & 10.3 & 3.0 & 7.3 \\
\hline Burundi & 6.9 & 339.4 & 7.6 & 0.5 & 7.1 \\
\hline Kenya & 4.9 & 15.2 & 10.6 & 8.4 & 2.2 \\
\hline Seychelles & 4.6 & 481.8 & 6.8 & 1.5 & 5.3 \\
\hline Cape Verde & 3.9 & 236.0 & 4.7 & 0.9 & 3.9 \\
\hline Botswana & 3.8 & 25.2 & 1.7 & 1.7 & 0.0 \\
\hline Mauritania & 3.1 & 86.4 & 3.9 & 2.5 & 1.5 \\
\hline Central African Republic & 2.7 & 137.3 & 4.0 & 0.4 & 3.6 \\
\hline Chad & 1.6 & 19.2 & 2.5 & 1.7 & 0.8 \\
\hline Guinea & 1.6 & 33.0 & 2.7 & 2.9 & -0.2 \\
\hline Burkina Faso & 1.5 & 17.5 & 3.2 & 2.1 & 1.2 \\
\hline Malawi & 1.4 & 27.3 & 3.3 & 0.9 & 2.4 \\
\hline Sao Tome and Principe & 1.1 & 531.3 & 1.4 & 0.2 & 1.2 \\
\hline Lesotho & 1.0 & 45.8 & 1.5 & 0.7 & 0.7 \\
\hline Swaziland & 1.0 & 26.9 & 1.1 & 0.6 & 0.5 \\
\hline Total 33 countries & 814.2 & 78.7 & 1065.8 & 188.6 & 877.2 \\
\hline
\end{tabular}


stem the outflow of capital. Angola, Burundi, Mozambique, Seychelles and Sierra Leone could double their rates of capital formation by sealing the leakage of capital.

\section{Capital losses through trade misinvoicing and unrecorded remittances}

Overall for the 33 countries as a group, the residual measure of capital flight amounted to $\$ 505.4$ billion over the $1970-2010$ period. Net trade misinvoicing contributed an additional $\$ 204.8$ billion to total capital flight, while unrecorded remittances added $\$ 104$ billion.

These aggregate numbers conceal wide cross-country variations in the relative size of these individual components (see Table A4 in the appendix). The following key combinations of patterns emerge with respect to trade misinvoicing (see Table 2 ):

1. Substantial export underinvoicing and import overinvoicing, both resulting in net outflows (positive sign), as in the cases of Côte d'Ivoire and Zimbabwe.

2. Substantial export underinvoicing (net outflows) coupled with import underinvoicing (net inflows), with the balance resulting in a net outflow, as in the case of Sudan or a net inflow, as in the cases of Ethiopia and Ghana.

3. Export overinvoicing (net inflows) coupled with import overinvoicing (net outflows), as in the case of Zambia.

4. Little net misinvoicing of either imports or exports, as in the case of Angola.

TABLE 2: TRADE MISINUOICING AND UNRECORDED REMTTANCES, 1970-2010: SOME EXAMPLS (MILLION, CONSTANT 2010 DOLLAR)

\begin{tabular}{|l|r|r|r|r|r|r|}
\hline Country & $\begin{array}{c}\text { Total } \\
\text { capital } \\
\text { flight }\end{array}$ & $\begin{array}{c}\text { Unadjusted } \\
\text { 'residual' } \\
\text { measure }\end{array}$ & $\begin{array}{c}\text { Export } \\
\text { misinvoicing }\end{array}$ & $\begin{array}{c}\text { Import } \\
\text { misinvoicing }\end{array}$ & $\begin{array}{c}\text { Total trade } \\
\text { misinvoicing }\end{array}$ & $\begin{array}{c}\text { Unrecorded } \\
\text { remittances }\end{array}$ \\
\hline Angola & 84.0 & 70.3 & 0.02 & -0.1 & -0.1 & 13.8 \\
\hline Cote d'Ivoire & 56.0 & 42.8 & 10.0 & 1.4 & 11.5 & 1.8 \\
\hline Ethiopia & 24.9 & 25.9 & 2.5 & -9.5 & -7.1 & 6.0 \\
\hline Ghana & 12.4 & 4.2 & 1.7 & -4.4 & -2.8 & 10.9 \\
\hline Sudan & 38.4 & 18.7 & 67.0 & -47.3 & 19.7 & 0.0 \\
\hline Zambia & 17.3 & 22.6 & -13.5 & 6.5 & -7.0 & 1.7 \\
\hline Zimbabwe & 18.3 & -5.1 & 5.3 & 11.5 & 16.8 & 6.5 \\
\hline All 33 countries & $\mathbf{8 1 4 . 2}$ & $\mathbf{5 0 5 . 4}$ & $\mathbf{3 8 5 . 2}$ & $\mathbf{- 1 8 0 . 3}$ & $\mathbf{2 0 4 . 8}$ & $\mathbf{1 0 4 . 0}$ \\
\hline
\end{tabular}

Source: Authors' computations.

Unrecorded remittances also contribute substantially to estimated capital flight in some countries. In Ethiopia, the volume of remittances reported by the World Bank in 2010 was about half the amount reported by the Central Bank (\$661 million). Even the latter was considered to be substantially lower than the actual flows 
given that large stock of immigrants. The true figure could be as high as one billion dollars. ${ }^{9}$ If so, Ethiopian capital flight would be commensurately larger than the estimate reported here.

\section{Capital flight compared to other flows}

While Sub-Saharan Africa is typically referred to as a heavily indebted, aid-dependent region, in reality the sub-continent appears to have transferred to the rest of the world more than it has received. Between 1970 and 2010, the 33 countries received a total of $\$ 659.5$ billion in official development assistance and attracted $\$ 306.4$ billion in foreign direct investment (Table 3). ${ }^{10}$ Capital flight exceeded ODA and FDI combined in the 1970s and 1980s. The cumulative amount of capital flight over the four decades represents 84.2 percent of ODA and FDI combined. The nine leading oil-exporting countries received a total of $\$ 186$ billion of ODA (50.8 percent of the total for the sample) and $\$ 186$ billion of FDI (28.2\%), compared to $\$ 590.7$ billion in total capital flight $(72.5 \%)$.

It is often reported that SSA countries have benefited from an increase in ODA and FDI over the last decade, which may have supported the observed higher growth before the global crisis. ${ }^{11}$ This can be seen in Figure 3 (page 12) for the group of 33 SSA countries covered in this report. But what is also evident is that in these countries capital flight also accelerated in this period. Indeed, capital flight outpaced ODA and FDI since 2000.

TABLE 3: CAPITAL FLIGHT, FDI AND ODA: CUMULATIVE VALUE (BILLION, CONSTANT 2010 DoLLARS)

\begin{tabular}{|l|r|r|r|r|r|}
\hline \multicolumn{1}{|c|}{ Period } & \multicolumn{1}{c|}{ FDI } & \multicolumn{1}{c|}{ ODA } & Net transfers on debt & \multicolumn{2}{c|}{ Capital flight } \\
\hline $1970-79$ & billion $\$$ & billion $\$$ & billion $\$$ & billion $\$$ & percent of FDI+ODA (\%) \\
\hline $1980-89$ & 23.3 & 63.3 & 81.3 & 116.9 & 134.9 \\
\hline $1990-99$ & 18.7 & 132.6 & 62.1 & 205.4 & 135.8 \\
\hline $2000-10$ & 53.7 & 181.1 & -20.1 & 138.4 & 59.0 \\
\hline $1970-2010$ & 210.7 & 282.5 & 5.4 & 353.5 & 71.7 \\
\hline of which: oil-exporting countries & 165.1 & 206.1 & 128.6 & 814.2 & \\
\hline Percentage of total & 53.9 & 31.2 & 12.1 & 590.7 & 84.3 \\
\hline
\end{tabular}

Source: Capital flight: authors' computations; ODA, FDI, and net transfers on debt are from the World Bank's Global Development Finance.

${ }^{9}$ See World Bank and AfDB (2011) Leveraging Migration for Africa Remittances, Skills, and Investments. Washington DC: World Bank.

${ }^{10}$ To make total ODA and FDI flows comparable to total capital flight, the series of ODA and FDI are matched with those of capital flight by considering for each country only the years where capital flight is not missing. The overall (unmatched) total ODA and FDI flows to the group as a whole are $\$ 674.6$ billion and $\$ 316.3$ billion, respectively.

${ }^{11}$ See African Economic Outlook 2010-12. 
FIGURE 3: CAPITAL FLIGHT, FDI, AND ODA, 10-YEAR CUMULATIVE FLOWS ( BILLION, CONSTANT 2010 DOLLARS)

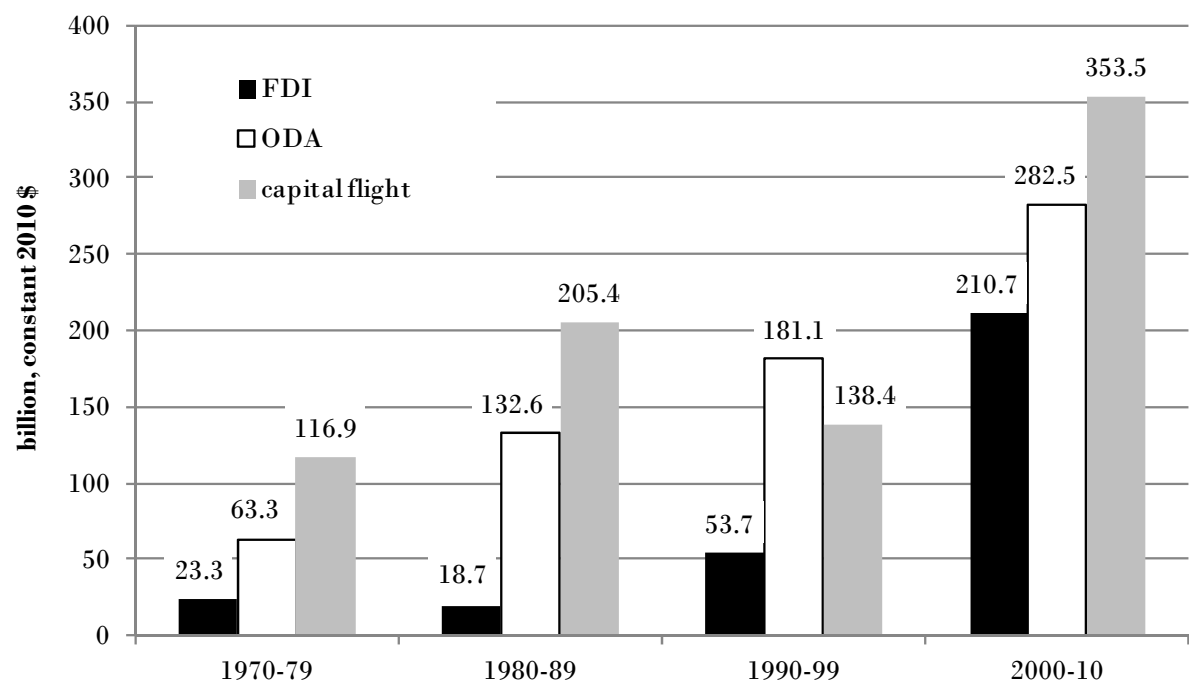

Source: Capital flight data are from authors' computations; FDI and ODA are from World Development Indicators. Nominal values are deflated using the US GDP deflator (base 2010=100).

As sub-Saharan African countries accumulated large amounts of external debt, debt service often more than matched new borrowing, resulting in negative net transfers on debt (Figure 4). In the 1990s, the cumulative net transfers on debt from the 33 countries as a group were negative ( $-\$ 20$ billion, Table 3$)$. Net external debt inflows increased since early 2000 s partly as a result of the implementation of debt relief mechanisms under the HIPC initiative. The timing of the upswing of these flows coincides with the escalation of capital flight, illustrating the close relationship between external borrowing and capital flight, or 'revolving door,' which we have documented in earlier studies (Ndikumana and Boyce 2003, 2011a, 2011b).

FIGURE 4: NET TRANSFERS ON DERT FOR THE 33 COUNTRIES

( BILLION, CONSTANT 2010 DOLLARS)

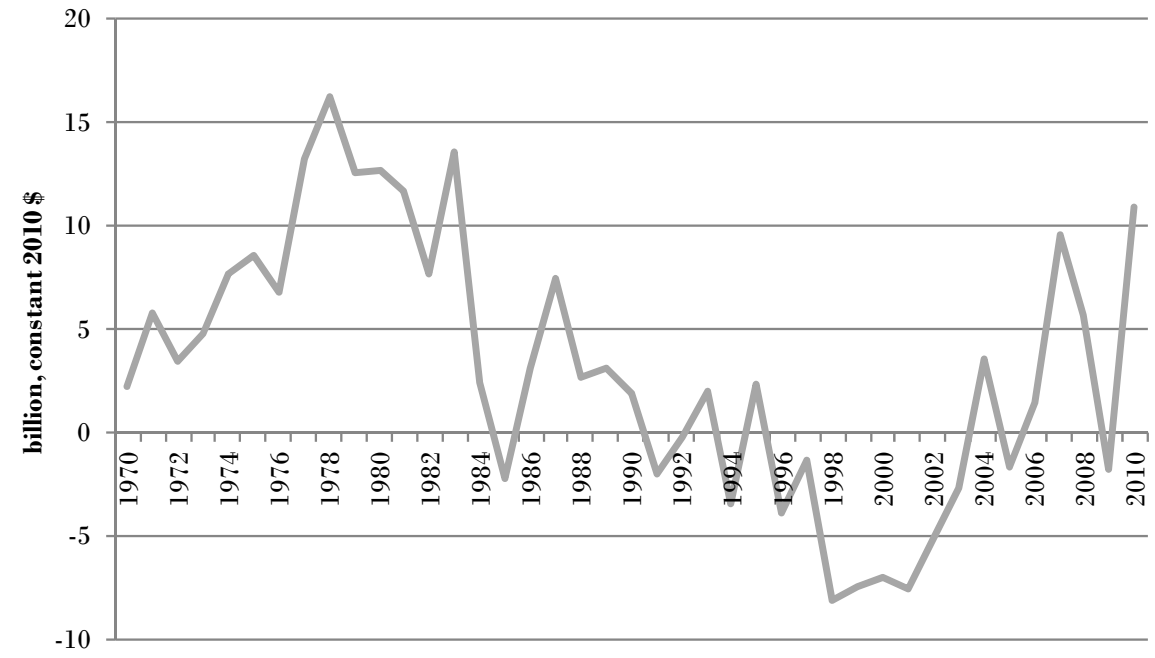

Source: World Bank's Global Development Finance. 


\section{CAPITAL FLIGHT IS A SERIOUS DEVELOPMENT CHALLENGE}

As Sub-Saharan African countries attempt to mobilize more resources for development, they must pay much more attention to capital flight for several reasons.

First, by draining valuable national resources, capital flight widens the resource gaps faced by these countries, perpetuating their dependence on external aid. Moreover, by deepening the resource gaps, capital flight slows down capital accumulation and long-run growth.

Second, capital flight frustrates African countries' efforts to increase domestic resource mobilization. It erodes the tax base and public expenditure through illicit transfer of private capital abroad, tax evasion and tax avoidance by individuals and companies, and outright embezzlement of government revenue by corrupt officials. These perverse effects force governments to incur further debts, part of which ends up fueling more capital flight (Ndikumana and Boyce 2011a, 2011b, 2010, 2003).

Third, by draining government revenues and retarding growth, capital flight undermines the poverty reduction agenda. It is estimated that if the capital that currently leaves Africa illegally was invested on the continent, the continent could meet the Millennium Development Goal of cutting poverty in half, a target it is otherwise likely to miss (AfDB, OECD, UNECA, and UNDP 2012).

Fourth, capital flight is both a symptom and an outcome of governance breakdown in source countries as well as in the international financial system. It is a result of corruption, dysfunctional regulation and weak enforcement of rules.

Fifth, capital flight worsens income inequality and it has important social and equity implications. Insofar as the perpetrators of capital flight, tax evasion and tax avoidance are the economic and the political elites, capital flight makes tax incidence more regressive in that wealthy residents incur relatively smaller tax burdens than would otherwise be the case.

Finally, capital flight has important political economy implications for the distribution of power. The political elites are able to consolidate power by financing their oppressive machinery with illicit wealth. As a result, capital flight strengthens dictatorships and provides the means to perpetuate autocratic regimes, as evidenced by the cases of Mobutu in the former Zaïre and the various military dictatorships in Nigeria, Gabon, and Equatorial Guinea (Ndikumana and Boyce 1998, 2011a).

Capital flight must move higher on the agenda in the development policy discourse not only in sub-Saharan Africa but also globally. Capital flight is not just an African problem; it is a symptom of a global financial system that is working badly.

CONCLUSION The evidence presented in this report demonstrates that capital flight is a severe drain on the resources of sub-Saharan African countries, and that it is worsening over time. The sub-continent has been transferring more capital abroad than it has 
received in public and private lending, ironically making it a 'net lender' to the rest of the world.

Capital flight frustrates efforts by African countries and their development partners aimed at scaling up financing for development to accelerate poverty reduction. It also has important social, political, equity and moral implications. It is therefore an urgent development challenge that requires coordinated policy actions at the national, continental and global levels. 


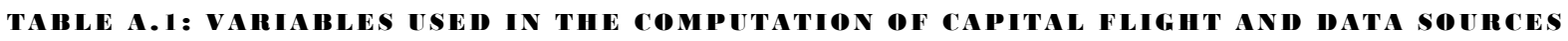

$D E B T$

$C A$

DFI

CRES

XTOT

$X I C$

MTOT

MIC

PMIC

$P X I C$

$C I F \_F O B$

USGDPD

TBILL
Total external public debt outstanding

Printed source: World Debt Tables

Electronic source: Balance of Payments (BOP) CDROM; International Financial

Statistics (IFS) CDROM; World Development Indicators/Global Development

Finance (WDI/GFI) Online

Current account deficits

Printed source: Balance of Payment Statistics Yearbook, Table 1

Electronic source: BOP CDROM; IFS CDROM; WDI/GFI Online

Direct foreign investment

Printed source: Balance of Payment Statistics Yearbook, Table 1

Electronic source: BOP CDROM; IFS CDROM; WDI/GFI Online

Change in reserves and related items

Printed source: Balance of Payment Statistics Yearbook, Table 1

Electronic source: BOP CDROM; IFS CDROM; WDI/GFI Online

Total exports to the world

Printed source: Direction of Trade Statistics Yearbook, part B

Electronic source: DOTS CDROM

Exports to industrialized countries as reported by the African country

Printed source: Direction of Trade Statistics Yearbook, part B

Electronic source: DOTS CDROM

Total imports from the world

Printed source: Direction of Trade Statistics Yearbook, part B

Electronic source: DOTS CDROM

The African country's imports from industrialized countries as reported by the African country

Printed source: Direction of Trade Statistics Yearbook, part B

Electronic source: DOTS CDROM

The African country's imports from industrialized countries as reported by industrialized countries

Printed source: Direction of Trade Statistics Yearbook, part A

Electronic source: DOTS CDROM

The African country's exports to industrialized countries as reported by industrialized countries

Printed source: Direction of Trade Statistics Yearbook, part A

Electronic source: DOTS CDROM

CIF/FOB factor

Either calculated using import data (DOT) or assumed to be 1.10

US GDP deflator

Printed source: International Financial Statistics Yearbook

Electronic source: IFS CDROM

US Treasury Bill rate

Printed source: International Financial Statistics Yearbook

Electronic source: IFS CDROM

Exchange rates of the French franc, Deutsche mark, Swiss franc, Pound sterling, Yen, and SDR against the dollar:

Printed source: International Financial Statistics Yearbook

Electronic source: IFS CDROM 


\begin{tabular}{|c|c|c|c|c|}
\hline Country & $\begin{array}{c}\text { Period } \\
\text { covered }\end{array}$ & $\begin{array}{l}\text { BoP variables } \\
\text { from printed } \\
\text { BoP }\end{array}$ & $\begin{array}{c}\text { BoP variables } \\
\text { from IMF country } \\
\text { staff reports }\end{array}$ & $\begin{array}{c}\text { No exchange rate } \\
\text { adjustment of } \\
\text { long-term debt }\end{array}$ \\
\hline Angola & $1985-2010$ & & & \\
\hline Botswana & $1975-2010$ & 1974 & & \\
\hline Burkina Faso & $1970-2010$ & $1970-73$ & 1995-99 & \\
\hline Burundi & $1985-2010$ & & & $1970-2000$ \\
\hline Cameroon & $1970-2010$ & $1970-76$ & & $1970-2000$ \\
\hline Cape Verde & $1977-2010$ & & & $1970-2000$ \\
\hline Central African Republic & $1970-2010$ & $1970-76$ & $1995-96,2009-10$ & \\
\hline Chad & $1977-2008$ & & & $1970-2000$ \\
\hline Congo, Democratic Republic & $1970-2010$ & $1970-76$ & $2009-10$ & \\
\hline Congo, Republic & 1970-2009 & $1970-77$ & & \\
\hline Cote d'Ivoire & $1970-2010$ & $1970-74$ & 2010 & \\
\hline Ethiopia & $1970-2010$ & $1970-76$ & & \\
\hline Gabon & $1978-2010$ & $1970-77$ & $2009-10$ & \\
\hline Ghana & $1970-2010$ & $1970-74$ & & \\
\hline Guinea & $1986-2010$ & & & \\
\hline Kenya & $1970-2010$ & $1970-74$ & & $1970-2000$ \\
\hline Lesotho & $1975-2010$ & & & $1970-2000$ \\
\hline Madagascar & $1970-2008$ & $1970-73$ & & \\
\hline Malawi & 1970-2009 & $1970-76$ & & \\
\hline Mauritania & $1973-2010$ & $1970-73$ & $2009-10$ & $1970-2000$ \\
\hline Mozambique & $1980-2010$ & & & $1970-2000$ \\
\hline Nigeria & $1970-2010$ & $1970-76$ & & \\
\hline Rwanda & $1970-2010$ & $1970-75$ & & \\
\hline Sao Tome and Principe & 1974-2010 & & & \\
\hline Seychelles & $1976-2010$ & & & \\
\hline Sierra Leone & $1970-2010$ & $1970-76$ & & \\
\hline South Africa & $1970-2010$ & & & $1970-2010$ \\
\hline Sudan & $1970-2010$ & $1970-73$ & & \\
\hline Swaziland & 1974-2010 & & & \\
\hline Tanzania & $1970-2010$ & $1970-75$ & & \\
\hline Uganda & $1970-2010$ & $1970-79$ & & \\
\hline Zambia & $1970-2010$ & $1970-77$ & 1993-96 & \\
\hline Zimbabwe & $1977-2010$ & $1970-76$ & $1995-2010$ & \\
\hline
\end{tabular}




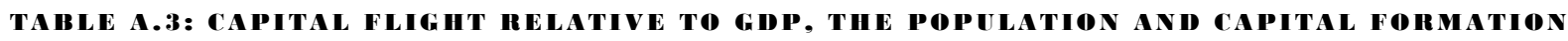

\begin{tabular}{|c|c|c|c|c|c|c|}
\hline \multirow[b]{2}{*}{ Country } & \multicolumn{3}{|c|}{ Total capital flight: 2010 values and ratios } & \multicolumn{3}{|c|}{ Annual average over 1970-2010 } \\
\hline & $\begin{array}{c}\text { Total real capital } \\
\text { flight, billion } \\
2010 \$\end{array}$ & $\begin{array}{c}\text { Total real } \\
\text { capital flight per } \\
\text { capita } 2010, \$\end{array}$ & $\begin{array}{l}\text { GDP per } \\
\text { Capita } \\
2010, \$\end{array}$ & $\begin{array}{c}\text { Capital } \\
\text { flight /GDP } \\
(\%)\end{array}$ & $\begin{array}{c}\text { Capital } \\
\text { flight per } \\
\text { capita }(\$)\end{array}$ & $\begin{array}{c}\text { Capital } \\
\text { fight/capital } \\
\text { formation }(\%)\end{array}$ \\
\hline Angola & 84.0 & 4401.1 & 4321.9 & 11.9 & 158.1 & 134.8 \\
\hline Botswana & 3.8 & 1872.0 & 7426.6 & 4.8 & 18.3 & -4.1 \\
\hline Burkina Faso & 1.5 & 93.7 & 535.9 & 0.2 & 6.4 & 8.1 \\
\hline Burundi & 6.9 & 820.7 & 241.8 & 2.0 & 26.1 & 154.3 \\
\hline Cameroon & 20.0 & 1020.8 & 1147.0 & 2.5 & 47.7 & 20.2 \\
\hline Cape Verde & 3.9 & 7893.7 & 3344.9 & 17.5 & 238.6 & 53.7 \\
\hline Central African Republic & 2.7 & 619.2 & 451.0 & 1.3 & 25.3 & 40.3 \\
\hline Chad & 1.6 & 146.0 & 760.7 & 0.4 & 7.8 & 17.0 \\
\hline Congo, Democratic Republic & 33.9 & 513.4 & 198.7 & 1.2 & 26.1 & 59.3 \\
\hline Congo, Republic & 19.9 & 4916.6 & 2970.1 & 12.6 & 147.9 & 39.5 \\
\hline Cote d'Ivoire & 56.0 & 2838.3 & 1161.2 & 6.8 & 128.2 & 72.5 \\
\hline Ethiopia & 24.9 & 299.9 & 357.9 & 0.8 & 10.7 & 31.4 \\
\hline Gabon & 25.5 & 16911.3 & 8767.8 & 41.0 & 597.4 & 28.6 \\
\hline Ghana & 12.4 & 506.5 & 1319.1 & 1.3 & 18.1 & 29.1 \\
\hline Guinea & 1.6 & 156.5 & 474.5 & 0.5 & 9.7 & 8.2 \\
\hline Kenya & 4.9 & 120.7 & 794.8 & 0.3 & 11.2 & 7.6 \\
\hline Lesotho & 1.0 & 459.4 & 1003.7 & 0.9 & 15.7 & 9.0 \\
\hline Madagascar & 11.7 & 564.4 & 421.0 & 1.5 & 30.0 & 56.6 \\
\hline Malawi & 1.4 & 92.7 & 339.2 & 0.2 & 8.6 & 15.3 \\
\hline Mauritania & 3.1 & 902.7 & 1044.5 & 2.1 & 37.9 & 35.8 \\
\hline Mozambique & 20.7 & 885.6 & 393.7 & 2.3 & 34.2 & 110.1 \\
\hline Nigeria & 311.4 & 1965.8 & 1242.5 & 4.7 & 67.7 & n.a. \\
\hline Rwanda & 9.3 & 876.9 & 529.4 & 1.8 & 46.5 & 69.2 \\
\hline Sao Tome and Principe & 1.1 & 6458.4 & 1215.5 & 14.1 & 212.8 & n.a. \\
\hline Seychelles & 4.6 & 53624.7 & 11129.8 & 96.5 & 1611.2 & 135.9 \\
\hline Sierra Leone & 10.0 & 1704.2 & 325.5 & 3.9 & 64.8 & 230.6 \\
\hline South Africa & 38.5 & 769.9 & 7271.7 & 1.4 & 30.9 & 7.9 \\
\hline Sudan & 38.4 & 1142.9 & 1538.3 & 2.8 & 34.9 & 15.6 \\
\hline Swaziland & 1.0 & 941.1 & 3503.2 & 1.6 & 27.9 & 11.3 \\
\hline Tanzania & 14.7 & 327.1 & 526.6 & 0.7 & 22.2 & 6.2 \\
\hline Uganda & 8.4 & 252.1 & 514.5 & 0.7 & 9.9 & 29.0 \\
\hline Zambia & 17.3 & 1336.6 & 1252.7 & 3.2 & 64.9 & 55.7 \\
\hline Zimbabwe & 18.3 & 1452.5 & 594.7 & 2.7 & 45.9 & 60.1 \\
\hline Total / average & 814.2 & 1072.8 & 1364.0 & 2.6 & 115.2 & $\mathbf{5 0 . 0}$ \\
\hline
\end{tabular}

Source: Authors' computation 
TABLE A.4: ADJUSTMENT FOR TRADE MISINUOICING ANDUNRECORDED REMITTANCES, $1970-2010$ ( BILLION, CONSTANT 2010 s)

\begin{tabular}{|c|c|c|c|c|c|c|}
\hline Country Name & $\begin{array}{c}\text { Total capital } \\
\text { flight }\end{array}$ & $\begin{array}{c}\text { Unadjusted } \\
\text { 'residual' measure }\end{array}$ & $\begin{array}{c}\text { Export } \\
\text { misinvoicing }\end{array}$ & $\begin{array}{c}\text { Import } \\
\text { misinvoicing }\end{array}$ & $\begin{array}{l}\text { Total trade } \\
\text { misinvoicing }\end{array}$ & $\begin{array}{l}\text { Unrecorded } \\
\text { remittances }\end{array}$ \\
\hline Angola & 84.0 & 70.3 & 0.02 & -0.1 & -0.1 & 13.8 \\
\hline Botswana & 3.8 & 3.8 & 0.0 & 0.0 & 0.0 & 0.0 \\
\hline Burkina Faso & 1.5 & 0.6 & 0.1 & 0.9 & 0.9 & 0.0 \\
\hline Burundi & 6.9 & 3.4 & 2.3 & 0.1 & 2.4 & 1.1 \\
\hline Cameroon & 20.0 & 1.1 & 26.2 & -9.6 & 16.6 & 2.3 \\
\hline Cape Verde & 3.9 & -0.1 & 0.2 & -1.1 & -0.9 & 4.9 \\
\hline Central African Republic & 2.7 & 0.7 & 1.0 & 0.1 & 1.1 & 0.9 \\
\hline Chad & 1.6 & 1.0 & 0.1 & 0.0 & 0.1 & 0.5 \\
\hline Congo, Democratic Republic & 33.9 & 9.5 & 25.5 & -10.3 & 15.3 & 9.1 \\
\hline Congo, Republic & 19.9 & 8.7 & 14.9 & -8.4 & 6.5 & 4.7 \\
\hline Cote d'Ivoire & 56.0 & 42.8 & 10.0 & 1.4 & 11.5 & 1.8 \\
\hline Ethiopia & 24.9 & 25.9 & 2.5 & -9.5 & -7.1 & 6.0 \\
\hline Gabon & 25.5 & 21.0 & 3.8 & -0.3 & 3.4 & 1.0 \\
\hline Ghana & 12.4 & 4.2 & 1.7 & -4.4 & -2.8 & 10.9 \\
\hline Guinea & 1.6 & 1.6 & 2.4 & -3.4 & -0.9 & 0.8 \\
\hline Kenya & 4.9 & -5.5 & 24.0 & -13.5 & 10.4 & 0.0 \\
\hline Lesotho & 1.0 & 1.0 & 0.0 & 0.0 & 0.0 & 0.0 \\
\hline Madagascar & 11.7 & 9.0 & 8.0 & -11.1 & -3.1 & 5.8 \\
\hline Malawi & 1.4 & -2.5 & -0.2 & 2.8 & 2.7 & 1.2 \\
\hline Mauritania & 3.1 & 3.0 & 1.7 & -3.0 & -1.3 & 1.4 \\
\hline Mozambique & 20.7 & 16.8 & 2.1 & -3.1 & -1.0 & 4.9 \\
\hline Nigeria & 311.4 & 273.2 & 52.2 & -14.0 & 38.2 & 0.0 \\
\hline Rwanda & 9.3 & -1.6 & 7.4 & 2.3 & 9.7 & 1.2 \\
\hline Sao Tome and Principe & 1.1 & 0.1 & 0.0 & 0.0 & 0.0 & 1.0 \\
\hline Seychelles & 4.6 & 0.8 & 3.9 & -0.4 & 3.5 & 0.3 \\
\hline Sierra Leone & 10.0 & 2.1 & 6.4 & -1.5 & 4.9 & 3.1 \\
\hline South Africa & 38.5 & -33.8 & 127.9 & -69.6 & 58.4 & 13.9 \\
\hline Sudan & 38.4 & 18.7 & 67.0 & -47.3 & 19.7 & 0.0 \\
\hline Swaziland & 1.0 & 1.0 & 0.0 & 0.0 & 0.0 & 0.0 \\
\hline Tanzania & 14.7 & 7.5 & 2.9 & -0.9 & 2.1 & 5.1 \\
\hline Uganda & 8.4 & 3.6 & -0.7 & 5.5 & 4.8 & 0.0 \\
\hline Zambia & 17.3 & 22.6 & -13.5 & 6.5 & -7.0 & 1.7 \\
\hline Zimbabwe & 18.3 & -5.1 & 5.3 & 11.5 & 16.8 & 6.5 \\
\hline All 33 countries & 814.2 & 505.4 & 385.2 & -180.3 & 204.8 & 104.0 \\
\hline
\end{tabular}

Source: Authors' computation. 
TABLE A.5:CAPITAL FLIGHT BY COUNTRY, ANNUAL TIME SERIES 1970-2010 (MILLION, CONSTANT 2010 s)

\begin{tabular}{|c|c|c|c|c|c|c|c|c|c|c|c|c|}
\hline Country & 1970 & 1971 & 1972 & 1973 & 1974 & 1975 & 1976 & 1977 & 1978 & 1979 & 1980 & 1981 \\
\hline \multicolumn{13}{|l|}{ Angola } \\
\hline Botswana & & & & & & -172.9 & -168.9 & -59.8 & -491.5 & -121.7 & -292.2 & -238.0 \\
\hline Burkina Faso & 80.1 & 69.8 & 28.7 & 55.1 & 161.6 & -53.6 & -19.3 & 155.5 & 290.6 & 38.6 & 243.7 & 142.7 \\
\hline \multicolumn{13}{|l|}{ Burundi } \\
\hline Cameroon & -21.5 & -78.3 & -369.1 & -731.1 & -3.8 & 201.8 & -227.8 & 1359.7 & 1093.3 & 1399.0 & 508.3 & 755.6 \\
\hline Cape Verde & & & & & & & & 53.5 & 71.1 & 90.7 & 40.8 & 151.2 \\
\hline Central African Rep. & 78.0 & 67.6 & 31.1 & 124.3 & 31.6 & 107.1 & 64.1 & -6.9 & 8.1 & 26.6 & -33.8 & 255.2 \\
\hline Chad & & & & & & & & 149.2 & 251.8 & 153.7 & 41.6 & -21.1 \\
\hline Congo, Democratic Republic & 1266.5 & 51.7 & 1033.8 & 3682.5 & 3276.7 & -55.9 & 1052.0 & -2942.3 & 3466.7 & 1643.1 & 1638.5 & 2155.9 \\
\hline Congo, Republic & 0.0 & 110.2 & 35.4 & 328.0 & -549.5 & -970.2 & -1344.3 & 3.8 & 640.0 & 524.2 & 219.8 & -589.2 \\
\hline Cote d'Ivoire & 325.5 & 564.5 & 545.1 & 621.0 & 470.8 & 1438.0 & 1060.2 & 2891.3 & 2344.9 & 698.8 & 3590.6 & 1193.6 \\
\hline Ethiopia & 57.3 & 13.2 & -597.2 & 155.6 & -78.8 & -78.6 & -309.0 & -76.3 & 170.3 & 18.5 & -103.2 & 1453.2 \\
\hline Gabon & & & & & & & & & 889.8 & 1200.6 & 970.7 & 931.2 \\
\hline Ghana & -48.0 & -757.4 & 465.7 & 630.2 & -745.0 & 47.7 & -182.6 & 601.3 & 517.4 & 289.1 & 729.0 & -348.6 \\
\hline \multicolumn{13}{|l|}{ Guinea } \\
\hline Kenya & 611.1 & 281.9 & 75.7 & 652.7 & 995.2 & 697.9 & 487.2 & 395.7 & 685.4 & 510.8 & 595.3 & -624.2 \\
\hline Lesotho & & & & & & 8.8 & -97.6 & -1.0 & 53.6 & 54.5 & 87.8 & 49.7 \\
\hline Madagascar & 1670.3 & -200.5 & 375.7 & -236.8 & 854.7 & 606.0 & -1592.8 & 1978.1 & -1229.2 & 69.2 & 301.6 & 990.9 \\
\hline Malawi & 104.0 & 18.9 & -52.2 & 225.0 & 229.8 & 339.6 & 237.3 & 399.6 & 110.9 & -336.2 & -55.1 & -3.3 \\
\hline Mauritania & & & & 449.9 & 511.6 & -260.7 & 381.8 & 138.2 & 187.8 & 14.3 & 114.8 & -235.8 \\
\hline Mozambique & & & & & & & & & & & -649.3 & -620.6 \\
\hline Nigeria & -212.8 & -712.1 & 839.8 & 4207.9 & 3050.8 & 3724.5 & 7104.1 & 13565. & 5552.4 & 1576.3 & 3387.0 & 10728. \\
\hline Rwanda & -114.1 & 25.6 & 32.3 & 76.6 & 62.7 & 95.2 & 160.2 & 171.9 & 1727.1 & 4365.2 & 1843.5 & 11.5 \\
\hline Sao Tome and Principe & & & & & 12.8 & 9.5 & -33.1 & 22.3 & 35.4 & 55.9 & 68.6 & 17.4 \\
\hline Seychelles & & & & & & & 1.6 & 6.4 & 7.5 & -22.3 & 206.6 & 72.9 \\
\hline Sierra Leone & 74.3 & 285.0 & 49.1 & 334.7 & 243.8 & -47.2 & 147.2 & 225.7 & 98.9 & 306.3 & 393.5 & 555.6 \\
\hline South Africa & -2066.9 & -3728.5 & 340.2 & -56.6 & -1958.9 & -6988.4 & 1255.0 & 6546.0 & 8171.5 & 9432.0 & 6552.4 & -8270.6 \\
\hline Sudan & 154.7 & -275.8 & -370.1 & 223.3 & 754.3 & 321.9 & 608.7 & 602.8 & 104.5 & 1050.1 & 1361.9 & -82.5 \\
\hline Swaziland & & & & & 126.7 & 89.9 & 62.9 & 82.7 & 85.4 & -31.1 & -252.1 & -10.4 \\
\hline Tanzania & 1367.9 & 4034.1 & -185.7 & 1181.9 & 1333.4 & 895.4 & 765.5 & 900.4 & 1027.2 & -43.6 & 1417.6 & 896.5 \\
\hline Uganda & 376.0 & -160.3 & -28.8 & 236.5 & 114.5 & -52.5 & 136.7 & -700.2 & -202.9 & 722.1 & 566.8 & 282.1 \\
\hline Zambia & 2834.3 & 229.3 & 289.3 & -1321.9 & -309.5 & -80.8 & 156.6 & 562.6 & 677.5 & 1004.8 & 81.9 & 1255.0 \\
\hline Zimbabwe & & & & & & & & 273.2 & 745.1 & -24.5 & 589.9 & 1249.4 \\
\hline
\end{tabular}


TA HLE A.5 (CONTINUED): CAPITAL FLIGHT HY COUNTRY

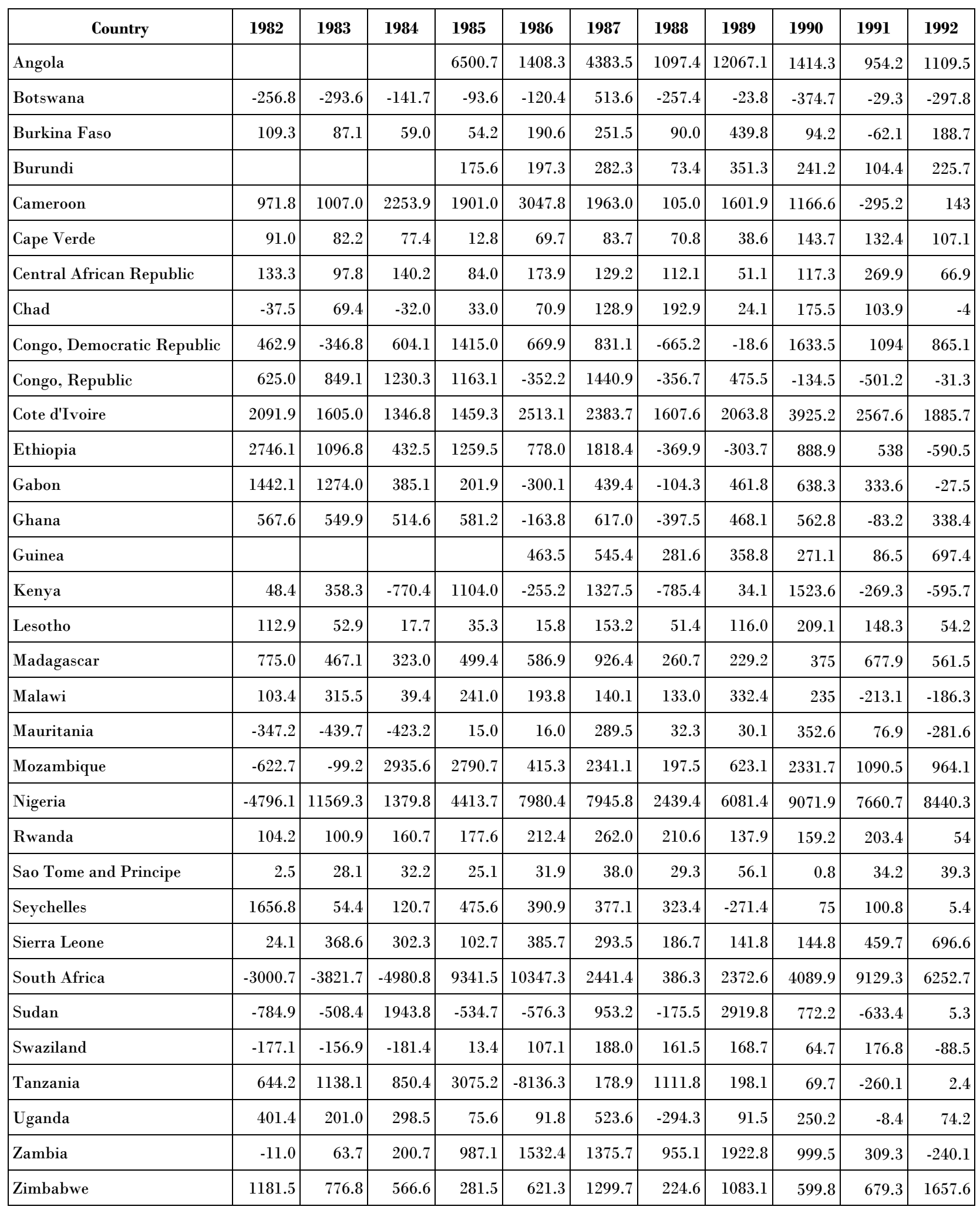


TA HLE A.5 (CONTINUED): CAPITAL FLIGHT HY COUNTRY

\begin{tabular}{|c|c|c|c|c|c|c|c|c|c|c|c|}
\hline Country & 1993 & 1994 & 1995 & 1996 & 1997 & 1998 & 1999 & 2000 & 2001 & 2002 & 2003 \\
\hline Angola & 969.5 & 1079.5 & 810.3 & 8281.4 & -683.2 & 885.2 & 65.2 & 1329.6 & 1342.3 & 2502.2 & 3442.4 \\
\hline Botswana & -286.3 & 135.9 & 242.6 & -34.3 & 193.0 & 220.5 & 244.8 & 286.7 & 1571.8 & -3756.8 & 1397.9 \\
\hline Burkina Faso & 172.8 & 249.8 & -141.0 & -169.7 & -272.4 & -158.5 & -268.0 & -98.8 & -49.2 & -126.2 & 461.0 \\
\hline Burundi & 193.1 & 156.9 & 503.5 & 302.2 & 109.9 & 277.4 & 139.9 & 181.4 & 238.5 & 372.2 & 367.9 \\
\hline Cameroon & -281.8 & 3350.1 & 2585.7 & 147.6 & -916.8 & 932.6 & -1082.5 & -26.3 & 6088.6 & -762.3 & -216.5 \\
\hline Cape Verde & 94.8 & 60.7 & 160.4 & 54.9 & 270.1 & 61.2 & 77.9 & 39.5 & 138.3 & 61.2 & 130.5 \\
\hline Central African Republic & 40.5 & 116.4 & 125.7 & 11.1 & 35.3 & 44.1 & -10.0 & -27.9 & -25.3 & 288.9 & -15.6 \\
\hline Chad & 13.0 & 117.8 & 57.3 & 94.1 & 61.0 & 22.0 & 0.1 & -62.6 & 88.6 & 212.5 & 796.7 \\
\hline Congo, Republic & 41.2 & -362.1 & 157.0 & -1389.0 & 309.7 & -110.4 & 394.4 & 3549.2 & 914.6 & -49.4 & 2119.9 \\
\hline Cote d'Ivoire & 2315.6 & 73.7 & 2488.2 & 1610.1 & 1810.4 & -104.3 & -599.8 & 3629.7 & -680.2 & 1342.2 & 3271.5 \\
\hline Ethiopia & -327.9 & 226.0 & 139.5 & 26.8 & 614.9 & 456.5 & -675.6 & 406.2 & 2518.0 & 3073.4 & 1598.4 \\
\hline Gabon & 78.3 & 626.1 & 402.2 & 442.9 & 591.8 & -220.2 & -273.3 & 2939.5 & -78.3 & 144.0 & 1039.0 \\
\hline Ghana & 84.7 & 422.4 & 467.5 & 609.4 & -172.9 & 424.1 & -462.0 & 209.6 & 199.5 & 1041.0 & 397.8 \\
\hline Guinea & 1094.3 & 141.0 & -159.7 & -516.8 & 168.8 & 134.7 & 134.9 & -56.3 & -232.9 & 54.2 & -49.6 \\
\hline Kenya & 294.4 & -91.9 & 793.3 & -786.5 & -236.5 & 801.7 & -450.6 & 62.7 & 518.3 & 1826.4 & 1735.9 \\
\hline Lesotho & -7.2 & 119.7 & -113.8 & -153.5 & -222.8 & -150.8 & -29.1 & -84.0 & -134.0 & 303.8 & 220.6 \\
\hline Malawi & -36.6 & 59.0 & 384.7 & 138.4 & -365.6 & 503.0 & 225.1 & -63.5 & 19.5 & 45.9 & 61.5 \\
\hline Mauritania & 347.4 & 187.3 & 281.3 & 228.8 & 141.9 & -53.6 & 291.2 & -33.8 & 332.6 & 312.2 & 218.7 \\
\hline Mozambique & 1106.4 & 3964.8 & 964.2 & 471.1 & 941.3 & 1272.4 & -2093.9 & -45.2 & 1305.2 & 384.6 & -1564.1 \\
\hline Nigeria & 2622.5 & 813.5 & -918.9 & 1661.8 & -3356.8 & -2030.0 & 2170.9 & 517.6 & 3356.5 & 2723.1 & 13106.9 \\
\hline Rwanda & -27.8 & 207.1 & 143.5 & 19.5 & 20.6 & 60.0 & -60.2 & -37.9 & -121.0 & 21.3 & 17.3 \\
\hline Sao Tome and Principe & 33.2 & 10.4 & 26.5 & -11.2 & 21.2 & 50.6 & 90.7 & 32.6 & -12.0 & 24.6 & 3.1 \\
\hline Seychelles & -118.0 & 63.7 & 17.1 & -186.0 & 17.9 & 72.3 & 69.6 & 184.5 & -12.0 & 141.9 & 46.7 \\
\hline Sierra Leone & 271.8 & 338.9 & 208.4 & 233.6 & 329.5 & 351.4 & 127.5 & 102.2 & -74.7 & 291.7 & 183.4 \\
\hline South Africa & 2544.6 & 1132.0 & -4092.8 & -3226.0 & -9695.1 & 9962.4 & 10460.7 & 17971.3 & 22668.2 & 17372.2 & 454.4 \\
\hline Sudan & 257.1 & 284.4 & -153.6 & -1492.9 & -1411.6 & -349.1 & -829.1 & 1060.6 & -369.5 & -1810.8 & 2030.9 \\
\hline Swaziland & 92.9 & 108.9 & 4.3 & -73.7 & 182.6 & -134.8 & 82.9 & 16.8 & -69.7 & 285.6 & 227.1 \\
\hline Tanzania & -102.0 & 267.0 & 294.8 & 46.3 & -271.8 & 705.8 & 570.0 & 545.8 & -319.8 & 758.0 & 624.2 \\
\hline Uganda & -11.4 & 162.1 & 61.9 & -94.6 & 37.6 & -17.2 & -793.4 & 190.1 & 515.0 & 563.6 & 1047.0 \\
\hline Zambia & -1006.4 & 1427.1 & -134.6 & 432.0 & 1092.6 & 964.4 & 923.5 & 475.1 & -156.1 & -32.4 & 183.9 \\
\hline Zimbabwe & 677.7 & 196.3 & 905.0 & 946.7 & 1434.5 & 1352.1 & 822.4 & 1512.2 & 60.7 & -65.4 & -2375.0 \\
\hline
\end{tabular}


TA HLE A.5 (CONTINUED): CAPITAL FLIGHT HY COUNTRY

\begin{tabular}{|c|c|c|c|c|c|c|c|c|}
\hline Country & 2004 & 2005 & 2006 & 2007 & 2008 & 2009 & 2010 & Total \\
\hline Angola & 2519.1 & 5762.8 & 4205.0 & 10163.6 & 7155.0 & 2148.8 & 3067.8 & 83981.6 \\
\hline Botswana & 1290.0 & 765.1 & 1199.6 & 1010.6 & 631.8 & 1205.9 & 358.8 & 3757.1 \\
\hline Burkina Faso & -201.3 & -310.8 & -324.5 & -52.8 & 151.3 & 181.7 & -196.5 & 1542.7 \\
\hline Burundi & 196.4 & 404.3 & 464.6 & 318.4 & 169.5 & 839.0 & -6.4 & 6879.8 \\
\hline Cameroon & -1488.4 & -2619.6 & -938.6 & -668.8 & -660.0 & -458.1 & -729.8 & 20006.6 \\
\hline Cape Verde & 63.3 & 249.2 & 195.3 & 234.2 & 220.9 & 238.7 & 247.7 & 3915.3 \\
\hline Central African Republic & 77.1 & -62.2 & 74.2 & -8.6 & -36.4 & -91.0 & 59.9 & 2725.0 \\
\hline Chad & -206.3 & 3.0 & -138.8 & -198.6 & -520.9 & & & 1639.2 \\
\hline Congo, Democratic Republic & 392.4 & -80.7 & 784.7 & 3012.2 & 1715.3 & -411.6 & 1813.6 & 33869.1 \\
\hline Congo, Republic & 5318.7 & 1215.3 & 2133.4 & 535.2 & 2283.3 & & & 19877.2 \\
\hline Cote d'Ivoire & -63.2 & 3280.0 & 491.8 & 979.3 & -1123.0 & -1995.6 & 101.5 & 56021.8 \\
\hline Ethiopia & 1400.8 & -319.9 & 104.0 & 1695.6 & -263.8 & 1875.1 & 3407.7 & 24874.8 \\
\hline Gabon & 1436.7 & 2198.2 & 2145.5 & 927.3 & 2190.9 & 699.4 & 1433.0 & 25459.3 \\
\hline Ghana & 499.2 & -908.0 & 748.3 & 733.2 & 1445.0 & 678.0 & 1184.0 & 12354.7 \\
\hline Guinea & -325.4 & -725.5 & -10.9 & -127.2 & 26.6 & -538.0 & -154.2 & 1562.3 \\
\hline Kenya & 1087.6 & -929.3 & -973.5 & -303.4 & -1370.2 & -1952.8 & -2219.0 & 4891.3 \\
\hline Lesotho & 244.2 & -87.2 & -59.4 & -46.3 & -0.8 & 140.1 & -64.5 & 997.6 \\
\hline Madagascar & 21.4 & -117.1 & 321.2 & 415.3 & -440.2 & & & 11690.8 \\
\hline Malawi & 53.3 & -762.3 & -192.7 & -707.9 & -311.0 & -221.7 & & 1381.4 \\
\hline Mauritania & -30.0 & -15.5 & 226.1 & -170.4 & 197.7 & -245.9 & 284.4 & 3123.1 \\
\hline Mozambique & -15.5 & -657.9 & 1803.1 & 241.8 & 72.0 & 132.0 & 733.6 & 20713.7 \\
\hline Nigeria & 9812.1 & 29263.4 & 24307.3 & 26908.4 & 37990.8 & 29029.3 & 18454.6 & 311431.3 \\
\hline Rwanda & -141.9 & -161.5 & -130.1 & 50.9 & -192.3 & -274.3 & -317.7 & 9316.0 \\
\hline Sao Tome and Principe & 28.1 & -35.9 & 37.9 & 199.3 & 87.7 & -40.3 & 4.4 & 1057.4 \\
\hline Seychelles & 84.0 & -33.6 & 399.2 & 323.5 & 4.1 & 137.1 & -160.4 & 4633.2 \\
\hline Sierra Leone & 348.1 & 264.9 & -23.8 & 121.2 & 298.6 & 484.2 & 369.0 & 9999.3 \\
\hline South Africa & - & 999.2 & - & 5911.8 & 3691.0 & - & - & 38487.2 \\
\hline Sudan & 6413.8 & 5897.7 & -5628.5 & 21061.2 & 1966.1 & 345.6 & 3297.7 & 38405.3 \\
\hline Swaziland & 151.5 & -193.9 & 45.4 & 335.7 & -381.0 & -299.1 & 181.5 & 993.3 \\
\hline Tanzania & 1020.4 & 332.5 & -329.6 & -505.7 & -1062.6 & -216.7 & -151.2 & 14668.6 \\
\hline Uganda & -2488.9 & 263.0 & 4123.0 & 980.4 & 913.9 & 141.4 & -163.0 & 8425.5 \\
\hline Zambia & 1543.8 & 2077.2 & 2202.8 & 135.3 & -1779.7 & -2185.8 & -2359.4 & 17277.9 \\
\hline Zimbabwe & 48.2 & 186.8 & 3145.2 & 601.5 & -495.9 & -1696.4 & -801.7 & 18260.0 \\
\hline
\end{tabular}

Source: Authors'computation. 
African Development Bank (AfDB), OECD, UNECA and UNDP (2012) African Economic Outlook 2011, 2012. Paris and Tunis: OECD and AfDB.

AfDB, UNECA, AU, and UNDP (2011) Assessing Progress in Africa toward the Millennium Development Goals, 2011 (MDG Report 2011).

Baker, R. (2005) Capitalism's Achilles Heel: Dirty Money and How to Renew the Free-Market System. New York: John Wiley \& Sons.

Boyce, J. K. and L. Ndikumana (2001) "Is Africa a net creditor? New estimates of capital flight from severely indebted sub-Saharan African countries, 19701996." Journal of Development Studies 38 (2): 27-56.

Erbe, S. (1985) "The Flight of Capital from Developing Countries." Intereconometrics, Nov/Dec, pp. 268-75.

Henry, J.S. (2012) The Price of Offshore Revisited. Tax Justice Network, London, (July).

Kar, D. (2010) "The Drivers and Dynamics of Illicit Financial Flows from India: 1948-2008." Global Financial Integrity (November).

Kar, D. and K. Curcio (2011) "Illicit financial flows from developing countries: 2000-2009. Update with a focus on Asia." Global Financial Integrity (January).

Kar, D. and D. Cartwright-Smith (2010) "Illicit Financial Flows from Africa: Hidden Resource for Development". Global Financial Integrity (March).

Ndikumana, L. and J.K. Boyce (2011a) Africa's Odious Debts: How Foreign Loans and Capital Flight Bled a Continent. London: Zed Books.

Ndikumana, L. and J.K. Boyce (2011b) "Capital flight from sub-Saharan African countries: linkages with external borrowing and policy options." International Review of Applied Economics 25(2): 149-70.

Ndikumana, L. and J.K. Boyce (2010) "Measurement of capital flight: methodology and results for sub-Saharan African countries." African Development Review 22 (4): 471-81.

Ndikumana, Léonce and James K. Boyce (2003) "Public Debts and Private Assets: Explaining Capital Flight from Sub-Saharan African Countries." World Development 31 (1), pp. 107-130.

Ndikumana, Léonce and James K. Boyce (1998) “Congo's Odious Debt: External Borrowing and Capital Flight in Zaire." Development and Change 29 (2): 195-217. 
UNDP (2011) Illicit Financial Flows from the Least Developed Countries: 1990-2008. Discussion Paper (May 2011)

World Bank and AfDB (2011) Leveraging Migration for Africa Remittances, Skills, and Investments. Washington DC: World Bank.

World Bank (1985) World Development Report 1985. Washington, D.C.: World Bank.

About the authors Léonce Ndikumana is Andrew Glyn Professor of economics at the University of Massachusetts. He is also Director of the African Policy Program at the Political Economy Research Institute. He is co-author (with James Boyce) of Africa's Odious Debt: How Foreign Loans and Capital Flight Bled a Continent, in addition to several dozens of academic articles and book chapters on African development and Macroeconomics. He is a graduate of the University of Burundi and received his doctorate from Washington University in St. Louis, Missouri.

James K. Boyce is professor of economics at the University of Massachusetts, Amherst, where he directs the program on development, peacebuilding, and the environment at the Political Economy Research Institute. He received his $\mathrm{PhD}$ in economics from Oxford University. His is the co-author (with Léonce Ndikumana) of Africa's Odious Debts: How Foreign Loans and Capital Flight Bled a Continent (Zed, 2011), and author of Investing in Peace: Aid and Conditionality After Civil Wars (Oxford University Press, 2002) and The Philippines: The Political Economy of Growth and Impoverishment in the Marcos Era (Macmillan, 1993).

\section{ABOUT THE POLITICAL ECONOMY RESEARCH INSTITUTE}

PERI was founded in 1998 as an independent research and academic unit within the University of Massachusetts, Amherst. The guiding ethos of PERI is to do rigorous academic research that is also broadly accessible, directly engaged with crucial economic policy issues, and maintains an abiding commitment to egalitarian values. PERI has a few broad and intersecting areas of specialty: the economics of clean energy, labor markets (especially low-wage work), financial markets and globalization; economic development (with a particular focus on Africa); the economics of peace; and environmental economics. Read more at the PERI website.

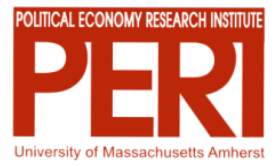

